\title{
Ground spiders (Arachnida, Araneae) associated with urban forest fragments in southern Amazon
}

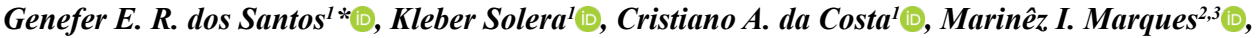 \\ Antonio D. Brescovit ${ }^{4}$ \& Leandro D. Battirola ${ }^{1}$ (iD \\ ${ }^{1}$ Universidade Federal de Mato Grosso, Instituto de Ciências Naturais, Humanas e Sociais, Programa de Pós- \\ Graduação em Ciências Ambientais, Sinop, MT, Brasil \\ ${ }^{2}$ Universidade Federal de Mato Grosso, Instituto de Biociências, Programa de Pós-Graduação em Zoologia, \\ Cuiabá, MT, Brasil \\ ${ }^{3}$ Universidade Federal de Mato Grosso, Instituto de Biociências, Programa de Pós-Graduação em Ecologia e \\ Conservação da Biodiversidade, Cuiabá, MT, Brasil \\ ${ }^{4}$ Instituto Butantan, Laboratório de Coleções Zoológicas, São Paulo, SP, Brasil \\ *Corresponding author: Genefer E.R.dos Santos, e-mail: geneferdossantos@gmail.com
}

DOS SANTOS, G.E.R., SOLERA, K., DA COSTA, C.A., MARQUES, M.I., BRESCOVIT, A.D., BATTIROLA, L.D. Ground spiders (Arachnida, Araneae) associated with urban forest fragments in southern Amazon. Biota Neotropica 20(4): e20201062. https://doi.org/10.1590/1676-0611-BN-2020-1062

\begin{abstract}
Forest fragments in urban areas comprise important habitats for a wide variety of species, however, conservationist policies for their maintenance and conservation are still incipient. This study examined the richness and abundance of the ground-spider assemblage in five forest fragments, with areas ranging between 18.5 and 103.98 ha, in the urban perimeter of Sinop, northern Mato Grosso State, southern Amazon region of Brazil. Sampling was carried out using the mini-Winkler extractor and pitfall traps in the dry (July) and rainy (November) seasons of 2017. All fragments were characterized in relation to the area and the Index of Biotic Integrity (IBI), to assess the effect of these variables on richness and abundance of soil spider assemblage. A total of 653 spiders were sampled, corresponding to 25 families and 52 species. Salticidae, Theridiidae, Lycosidae, Linyphiidae, Oonopidae and Symphytognathidae were the most abundant families (63.3\% of the total sample). The assemblage was characterized by the dominance of hunting spiders (393 ind.; $60.2 \%$ ) over web-building spiders (260 ind.; 39.8\%). Greater spider abundance and richness was obtained during the rainy season (517 ind.; $79.2 \%$; 41 spp.) as compared with the dry season (136 ind.; $20.8 \% ; 24$ spp.). Only 13 species occurred in dry and rainy season. Two species were recorded for the first time in the Amazon region, namely, Anapistula aquytabuera Rheims \& Brescovit, 2003 (Symphytognathidae) and Opopaea concolor (Blackwall, 1859) (Oonopidae). Species richness was not affected by IBI and area of fragment. Although the statistical model is not significant, species richness increases slightly with IBI and area of fragment. Similarly, abundance of spiders was not affected by IBI and area of fragment. Regardless of the area size, all evaluated forest fragments showed a low and regular IBI, demonstrating that these habitats have suffered with the pressures inherent from the urban perimeter, including the constant expansion of human occupation as well as misuse by the population. Nonetheless, these same fragments revealed considerable richness of species of ground spiders and can thus be categorized as important habitats for the maintenance of regional biodiversity. Therefore, action strategies must be set out to ensure their conservation. Keywords: Arachnids, Diversity, Temporal variation, Urban areas.
\end{abstract}

\section{Aranhas de solo (Arachnida, Araneae) associadas a fragmentos florestais urbanos no sul da Amazônia}

Resumo: Fragmentos florestais em áreas urbanas compreendem importantes habitats para uma grande variedade de espécies, entretanto, políticas conservacionistas ainda são incipientes para sua manutenção e conservação. Assim, avaliou-se a riqueza e abundância da assembleia de aranhas de solo em cinco fragmentos florestais, com áreas variando entre 18,5 e 103,98 ha, no perímetro urbano de Sinop, norte de Mato Grosso, sul da Amazônia. As amostragens foram efetuadas com Extrator mini-Winkler e armadilhas pitfall nos períodos de seca (julho) e chuva (novembro) de 2017. 
Os fragmentos foram caracterizados em relação à área e ao Índice de Integridade Biótica (IBI) para avaliar o efeito dessas variáveis sobre a riqueza e abundância da assembleia de aranhas de solo. Um total de 653 aranhas foi amostrado, compreendendo 25 famílias e 52 espécies. Salticidae, Theridiidae, Lycosidae, Linyphiidae, Oonopidae e Symphytognathidae corresponderam às famílias mais abundantes (63,3\% do total). Aranhas caçadoras (393 ind.; $60,2 \%$ ) predominaram em relação às tecelãs (260 ind.; 39,8\%). A maior abundância e riqueza de espécies de aranhas foram obtidas durante o período de chuva (517 ind.; 79,2\%; 41 spp.) em relação ao período de seca (136 ind.; 20,8\%; 24 spp.). Duas espécies foram registradas pela primeira vez na região Amazônica, Anapistula aquytabuera Rheims \& Brescovit, 2003 (Symphytognathidae) and Opopaea concolor (Blackwall, 1859) (Oonopidae). A riqueza de espécies não foi afetada pelo IBI nem pela área dos fragmentos. Embora o modelo estatístico não seja significativo, observa-se que a riqueza de espécies aumenta ligeiramente com o aumento do IBI e da área dos fragmentos. Da mesma forma, a abundância das aranhas não foi afetada pelo IBI e nem pela área do fragmento. Todos os fragmentos florestais avaliados, independente do tamanho da área, apresentaram um baixo ou regular IBI, evidenciando que estes habitats têm sofrido com as pressões inerentes do perímetro urbano incluindo a constante expansão da ocupação humana, bem como o mau uso por parte da população. Entretanto, estes mesmos fragmentos, evidenciaram considerável riqueza de espécies de aranhas de solo, podendo ser categorizados como importantes habitats para a manutenção da biodiversidade regional e, portanto, sendo necessária a definição de estratégias de ação que garantam sua conservação. Palavras-chave: Aracnídeos; Áreas urbanas; Diversidade; Variação temporal.

\section{Introduction}

Spiders are globally megadiverse, with just over 48,400 species described (World Spider Catalog 2020). In the Amazon, approximately 1,000 species are known, with estimates that this value can be greater than 2,000 species (Oliveira et al. 2017). This high species richness is related to the different foraging strategies, wide distribution across terrestrial ecosystems, as well as colonization of different habitats from the ground to the forest canopy (Marc et al. 1999, Höfer \& Brescovit 2001, Brescovit et al. 2002, Uehara-Prado et al. 2009, Cardoso et al. 2011, Nyffeler \& Birkhofer 2017).

The presence of spiders in certain habitats is often associated with the structural quality of ecosystems, due to the biological control effect exerted by these arachnids on different invertebrate populations (Silva \& Coddington 1996, Rosa et al. 2019). Because most spiders are predators, it is believed that their richness and abundance reflect the richness and abundance of other arthropods belonging to lower trophic levels in the same environment (Nogueira et al. 2006). Predators, such as spiders, are essential components in ecosystems in as much as they act as natural pest control agents besides influencing the community dynamics (Lessard-Therrien et al. 2018).

Spiders can respond to environmental changes, which characterizes them as potential bioindicators of disturbances in ecosystems (Malumbres-Olarte et al. 2013). The northern region of Mato Grosso State, Brazil, comprises the southern portion of the Amazon and its transition zone with the Cerrado biome. Due to the advance of the agricultural frontiers and livestock husbandry and the expansion of cities, the conversion of natural habitats into economically active areas has been accelerated in this region, causing sudden changes in the landscape (Araújo et al. 2019, Renó \& Novo 2019, Santos et al. 2019). The current result is a landscape mosaic consisting of remnants of natural vegetation isolated in fragments, both in urban and rural areas. These fragments are areas extremely vulnerable to habitat loss due to the interaction between natural changes, urbanization and intense human disturbances (Gong et al. 2013).

Therefore, it is necessary to understand the processes associated with fragmentation dynamics to understand how the biodiversity and ecosystem services provided by forest fragments can be compromised, mainly by a reduction in the number of species in these areas (Samu et al. 2018). In urban areas, biotic homogenization is an enormous challenge for conservation, as it has a dominant role in the loss of native species worldwide (McKinney 2006). Studies conducted in isolated forest remnants in different anthropogenic matrices show a need to understand this spatial and temporal dynamics, since they are fundamental factors for the conservation of animal communities, including spider assemblages (e.g. Candiani et al. 2005, Major et al. 2006, Mestre \& Gasnier 2008, Benati et al. 2010, Haddad et al. 2011, Rodríguez-Rodríguez et al. 2015).

Ground spiders are fundamental elements in the dynamics of the communities that inhabit forest fragments. Thus, their richness in these habitats must be further investigated, especially in regions such as the southern Amazon and its transition zone with the Cerrado. In view of the importance of such studies for the knowledge of regional biodiversity, this study was developed to examine the abundance and richness of the assemblage of ground spiders (Arachnida, Araneae) associated with forest fragments in the urban perimeter of Sinop, Mato Grosso, Brazil.

\section{Materials and Methods}

\section{Study area}

The study was developed in five forest fragments in the urban perimeter of Sinop - MT, Brazil (Figure 1, Table 1). Sinop is situated on the right bank of the Teles Pires River, $500 \mathrm{~km}$ from Cuiabá, the capital of Mato Grosso, in the Amazon Basin, in the lower Teles Pires, a sub-basin of the Amazon basin, in Planalto dos Parecis, at an altitude of $384 \mathrm{~m}$ (Botelho \& Secchi 2014). According to the Köppen classification system, the climate of the region is a rainy, hot and humid (Aw) tropical type, with an average annual temperature of $24^{\circ} \mathrm{C}$, characterized by a dry (May to October) and a rainy period (November to April). The average annual precipitation in the region is 1,800 to $2,000 \mathrm{~mm}$. The vegetation is a semi-deciduous forest type in the transition area between the Amazon and the Cerrado biome (Priante-Filho et al. 2004). 

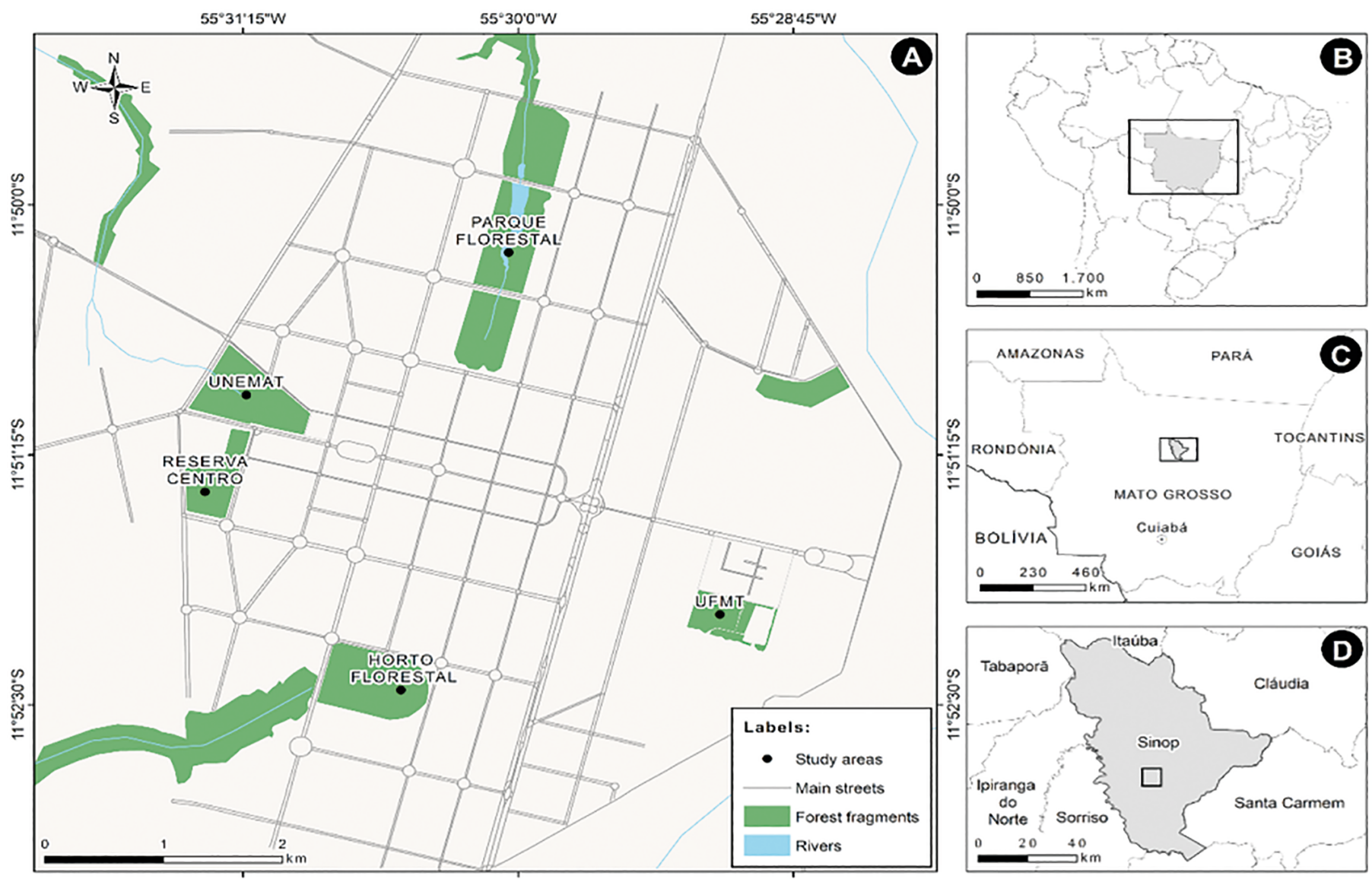

Figure 1. Location of forest fragments evaluated in the urban perimeter of Sinop - MT, Brazil.

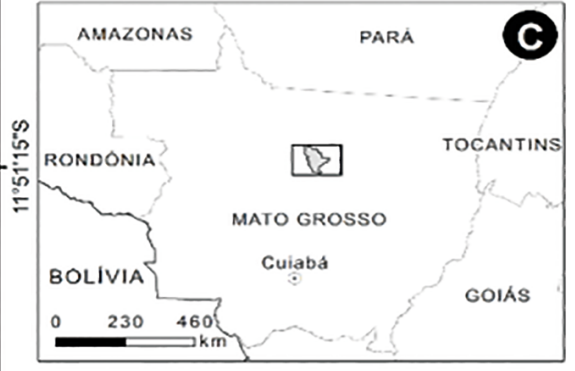

Table 1. Characterization of forest fragments in the urban perimeter of Sinop - MT, Brazil, used in this study.

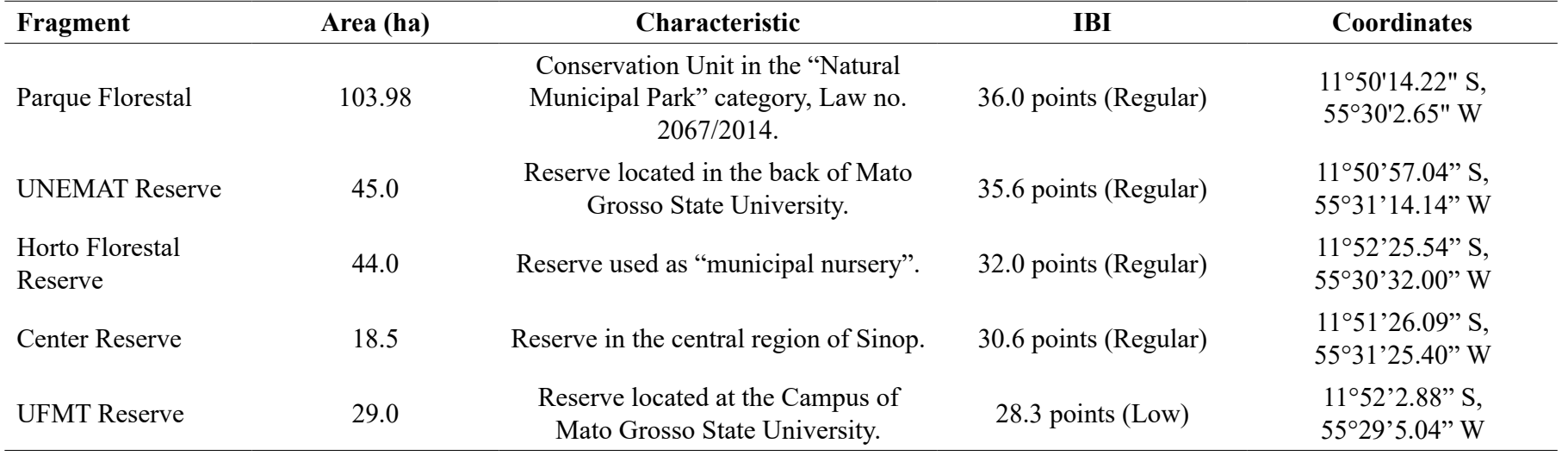

Each sampled fragment was characterized in terms of area and biotic integrity. The Index of Biotic Integrity (IBI), which was used for the evaluation, took into account its applicability on forest fragments in urban areas, in accordance with Graciano-Silva et al. (2018). Considering the small size of the fragments, with areas ranging between 18.5 and 103.98 ha (Table 1), the IBI was determined based on observations made in two $10 \times 10 \mathrm{~m}$ quadrants: one in the border area $(25$ $\mathrm{m}$ from the edge) and another within each fragment. The quadrants used to assess the IBI were located always close to the sampling quadrants of the soil spider assemblage.

\section{Methodology}

Ground spiders were sampled using the mini-Winkler extractor (Bestelmeyer et al. 2000) and pitfall traps (Adis 2002). Three independent sampling points were defined in each of the five urban forest fragments, spaced at least $100 \mathrm{~m}$ apart, and away from the edge $25 \mathrm{~m}$. Two $10 \times 10 \mathrm{~m}$ quadrants were delimited at each sampling point, one for sampling with the mini-Winkler extractor and the other for installing pitfall traps. Collections by both methods were carried out during the dry (July) and rainy (November) seasons of 2017. 
Sampling with the mini-Winkler extractor consists of two steps: collection of topsoil and plant litter in the field and extraction of organisms in the laboratory. In the quadrants intended for sampling with said device, five $1 \mathrm{~m}^{2}$ points were demarcated and portions of litter and topsoil were sieved, corresponding to $15 \mathrm{~m}^{2}$ of the sampled area per fragment, in each seasonal period. In total, $150 \mathrm{~m}^{2}$ of soil and litter were sampled, $75 \mathrm{~m}^{2}$ of which in each seasonal period (dry and rainy). After the field procedures, the sieved material was packed in nylon bags for extraction and transported to the laboratory. After being stored in the extractors, the material remained for $72 \mathrm{~h}$ at room temperature in the laboratory for the extraction of arthropods in general (e.g. Castilho et al. 2005).

The pitfall traps used in sampling consisted of polyethylene bottles $20 \mathrm{~cm}$ in height with a $5-6 \mathrm{~cm}$ circular opening, containing $250 \mathrm{~mL}$ of water and drops of neutral detergent, which were arranged on the ground to intercept the organisms during their movement. To prevent interference during sampling, such as leaf or rain falling into the traps, they were protected by plastic covers $(20 \times 20 \mathrm{~cm})$ supported by metal rods. Five traps were installed at a distance of $5 \mathrm{~m}$ from each other in the $10 \times 10 \mathrm{~m}$ quadrants, where they remained for $48 \mathrm{~h}$. Fifteen traps were used per forest fragment in each seasonal period. In total, 150 samples were obtained with the pitfall traps, consisting of 75 per period (dry and rainy).

All the sampled material was stored in plastic bottles containing $92 \%$ alcohol. Spiders were separated from other arthropods at the Arachnida and Myriapoda Laboratory of the Southern-Amazon Biological Collection of the Federal University of Mato Grosso, University Campus of Sinop, and subsequently identified at the Laboratory of Zoological Collections of the Butantan Institute, São Paulo - SP, Brazil, where they were deposited (Curator: AD Brescovit). Behavioral guilds were determined as proposed by Dias et al. (2010).

\section{Data analysis}

For the analysis, the results obtained with the pitfall traps and the mini-Winkler extractor were summed according to the sampling points, areas and periods, considering that both are complementary methodologies for the sampling of ground assemblages (Silva et al. 2013, Carneiro et al. 2016). The sampling of the ground-spider assemblage was evaluated by the Jackknife 1 estimator. Urban fragments were compared with respect to assemblage composition by the Jaccard Similarity Index, using BioDiversity Pro software (MacNeely 1997). Immatures were not used in these analyzes (Jackknife 1 and Jaccard). We tested GLM (GLM, glm function, vegan package, Oksanen et al. 2019) to understand the effects of IBI and fragment area on spider richness (given by the number of species per fragment) and spider abundance (given by the total on individuals sampled per fragment). The statistical test of significance was calculated by analyzing ANOVA type II square deviations (Anova function, car package, Fox \& Weisberg 2019). The GLM analyses and graphs (ggplot function, ggplot2 package, Wickham 2016) were done in $\mathrm{R}$ ( $\mathrm{R}$ Core Team 2020).

\section{Results}

A total of 653 spiders were sampled, corresponding to 488 immature individuals $(74.7 \%$ of the total sample) and 165 adults $(25.3 \%)$, comprising 25 families and 52 species. Among the adults, females corresponded to $67.9 \%$ (112 individuals) (Table 2). Singletons and doubletons represented $59.6 \%$ of the sampled species. Between the methodologies, the greatest abundance was obtained with mini-Winkler extractor (554 ind.; $84.8 \%$ of the total abundance), whereas only 99 individuals were sampled with the pitfall traps $(15.2 \%$ of the total abundance). Of this total, 517 spiders (79.2\%) were collected during the rainy season and 136 during the dry season (20.8\%). Species richness was also greater during the rainy season (41 spp.) compared to the drought period ( $24 \mathrm{spp}$.). Only 13 species were sampled in both periods.

Individuals of the families Salticidae (121 ind.; $18.5 \%$ of the total sample), Theridiidae (78 ind.; 12.0\%), Lycosidae (61 ind.; 9.3\%), Linyphiidae (57 ind.; 8.7\%), Oonopidae (51 ind.; $7.8 \%$ ) and Symphytognathidae (46 ind.; $7.0 \%$ ) were more abundant in the composition of the assemblage associated with the evaluated fragments, corresponding to $63.3 \%$ of the total of sampled individuals (Table 2). The families Anyphaenidae, Barychelidae, Dipluridae, Gnaphosidae, Segestriidae and Selenopidae were represented only by immature individuals (Table 2 and 3).

The abundance of ground spiders was similar between the analyzed fragments (average of 130.6 individuals per fragment). Parque Florestal had the highest abundance (148 individuals; $22.6 \%$ of the total sample), followed by the UFMT Reserve (146 individuals; $22.4 \%$ ), Horto Florestal (126 individuals; 19.3\%), the UNEMAT Reserve (123 ind.; $18.8 \%$ ) and the Center Reserve (110 ind.; 16.9\%) (Table 3). When the families sampled in each fragment were compared, the UFMT Reserve showed a greater variety ( 24 families out of the 25 sampled throughout the study), followed by the UNEMAT Reserve (18 families), Parque Florestal (16 families), and the Center Reserve and Horto Florestal (15 families each) (Table 3). The UFMT Reserve registered the exclusive occurrence of four families (Actinopodidae, Barychelidae, Deinopidae and Selenopidae), whereas Gnaphosidae occurred only in the UNEMAT Reserve. No exclusive families occurred in the other areas.

In terms of species richness, Parque Florestal was the fragment with the largest number of identified species ( $24 \mathrm{spp}$.), followed by the UNEMAT Reserve (20 spp.), Horto Florestal (17 spp.), the UFMT Reserve (15 spp.) and the Center Reserve (13 spp.) (Table 3). The Jackknife 1 estimator revealed that $67.7 \%$ of the species occurring in these fragments were sampled, with the possibility of reaching 76.8 species (Figure 2). The greatest similarity in the ground-spider assemblage composition was observed between the UNEMAT Reserve and Parque Florestal, followed by similarity between UFMT Reserve and Center Reserve (Figure 3). Species richness was not affected by IBI (Poisson GLM: $\chi^{2}=3.24 ; \mathrm{P}=0.072$, Figure $4 \mathrm{a}$ ) and fragment area (Poisson GLM: $\chi^{2}=3.48 ; \mathrm{P}=0.062$, Figure $4 \mathrm{c}$ ). Although the model is not significant, species richness increases slightly with IBI and fragment area. Similarly, abundance of spiders was not affected by IBI (Gaussian GLM: $\chi^{2}=0.01 ; \mathrm{P}=0.908$, Figure $4 \mathrm{~b}$ ) and fragment area (Gaussian GLM: $\chi^{2}=1.89 ; \mathrm{P}=0.169$, Figure $\left.4 \mathrm{~d}\right)$.

Two of the 52 species identified in this study were recorded for the first time in the Amazon region, namely, Anapistula aquytabuera Rheims \& Brescovit, 2003 (Symphytognathidae) and Opopaea concolor (Blackwall, 1859) (Oonopidae). It should be noted that this was also the first record of A. aquytabuera in the state of Mato Grosso. Opopaea concolor is an introduced species, and its distribution is extended to 
Table 2. Abundance of spiders (males, females and immatures) sampled in forest fragments in the urban area of Sinop - MT, Brazil, associated with the species richness per family and their distribution into behavioral guilds (NGA - nocturnal ground ambushers; NAH - nocturnal aerial hunters; AH - aerial hunters; OW - orb weavers; NGH - nocturnal ground hunters; GR - ground runners; GW - ground weavers; TWW - three-dimensional web weavers; NAA - nocturnal aerial ambushers; DAA - diurnal aerial ambushers).

\begin{tabular}{|c|c|c|c|c|c|c|c|}
\hline \multirow{2}{*}{ Families } & \multicolumn{5}{|c|}{ Abundance (N) } & \multirow{2}{*}{ Richness } & \multirow{2}{*}{$\begin{array}{c}\text { Behavioral } \\
\text { Guild }\end{array}$} \\
\hline & males & females & immatures & Total & $\%$ & & \\
\hline Salticidae & 6 & 16 & 99 & 121 & 18.5 & 10 & $\mathrm{NAH}$ \\
\hline Lycosidae & - & 1 & 60 & 61 & 9.3 & 1 & $\mathrm{NGH}$ \\
\hline Linyphiidae & 12 & 19 & 26 & 57 & 8.7 & 4 & TWW \\
\hline Zodariidae & - & 1 & 37 & 38 & 5.8 & 1 & GR \\
\hline Corinnidae & 4 & 1 & 29 & 34 & 5.2 & 3 & GR \\
\hline Ctenidae & - & 2 & 31 & 33 & 5.1 & 2 & NGA \\
\hline Hahniidae & 3 & 9 & 15 & 27 & 4.1 & 1 & GW \\
\hline Palpimanidae & 4 & 2 & 6 & 12 & 1.8 & 1 & $\mathrm{NGH}$ \\
\hline Pholcidae & 2 & 4 & 5 & 11 & 1.7 & 2 & TWW \\
\hline Thomisidae & 1 & 1 & 8 & 10 & 1.6 & 2 & DAA \\
\hline Oxyopidae & - & 1 & 4 & 5 & 0.7 & 1 & NAH \\
\hline Segestriidae & - & - & 4 & 4 & 0.6 & - & NAH \\
\hline Anyphaenidae & - & - & 3 & 3 & 0.4 & - & $\mathrm{AH}$ \\
\hline Dipluridae & - & - & 3 & 3 & 0.4 & - & GW \\
\hline Gnaphosidae & - & - & 2 & 2 & 0.3 & - & $\mathrm{NGH}$ \\
\hline Actinopodidae & 1 & - & - & 1 & 0.2 & 1 & NGA \\
\hline
\end{tabular}

Sinop, occurring in Horto Florestal, an area of marked urban influence. This species was known only from the Pantanal area of Poconé, in the south of the state (Brescovit et al. 2019).

Regarding the distribution of species across the forest fragments, only two occurred in all five fragments, namely, A. aquytabuera and Otiothops hoeferi Brescovit \& Bonaldo, 1993 (Table 3). Nine other species were sampled exclusively in Horto Florestal (Corythalia sp.1, Ctenus sp.1, Dipoena sp.2, Hamataliwa sp.1, Mangora sp.1, Neotrops sp.2, O. concolor, Thymoites sp.1 and Tmarus sp.1), eight in Parque Florestal (Castianeira sp.1, Castianeira sp.2, Dipoena sp.1, Epicratinus sp.1, Meioneta sp.1, Salticidae sp.2, Salticidae sp.8 and Scytodes sp.1), seven in the UNEMAT Reserve fragment (Bucranium taurifrons $(\mathrm{O}$. Pickard-Cambridge, 1881), Dipoena pumicata (Keyserling, 1886), Isoctenus sp.1, Meioneta sp.3, Stemmops sp.1, Thymoites sp.2 and Thymoites sp.3), five in the UFMT Reserve (Actinopus sp.1, Deinopis sp.1, Episinus sp.1, Guaraniella sp.1 and Lycosa sericovittata MelloLeitão, 1939) and three in the Center Reserve (Mesabolivar sp.1, Orchestina sp.1 and Uloborus sp.1) (Table 3).
With respect to the classification of spider families into behavioral guilds, the assemblage of ground spiders was characterized by the predominance of hunting spiders (393 ind.; $60.2 \%$ of the total) over web-building spiders (260 ind.; $39.8 \%$ of the total). Hunters correspond mainly to nocturnal aerial hunters (146 ind; $37.2 \%$ of the total of hunters) and nocturnal ground hunters (127 ind.; 32.3\%). Ground runners (72 ind.; 18.3\%), nocturnal ambushers (34 ind.; 8.6\%), diurnal aerial ambushers (10 ind.; 2.5\%), aerial hunters (3 ind.; $0.7 \%$ ) and nocturnal aerial ambushers ( 1 ind.; $0.2 \%$ ) were less abundant. Among the web builders, there was a dominance of three-dimensional web weavers (146 ind.; $56.1 \%$ of the total web builders), followed by orb weavers (83 ind.; $31.9 \%$ ), and ground weavers (31 ind.; 11.9\%).

\section{Discussion}

The assemblage of ground spiders associated with the urban forest fragments sampled in this study showed a similar pattern regarding the composition and distribution of the species across the five fragments, 
Table 3. Total abundance of ground spider's families, including the identified species ( ), distributed by forest fragments in the urban area of Sinop - MT, Brazil; (I - Center Reserve; II - Horto Florestal; III - Parque Florestal; IV - UNEMAT Reserve and V - UFMT Reserve).

\begin{tabular}{|c|c|c|c|c|c|c|c|}
\hline \multirow{2}{*}{\multicolumn{2}{|c|}{ Taxa }} & \multicolumn{5}{|c|}{ Urban Forest Fragments } & \multirow[b]{2}{*}{ Total } \\
\hline & & I & II & III & IV & $\mathbf{V}$ & \\
\hline Actinopodidae & & - & - & - & - & 1 & 1 \\
\hline Anyphaenidae & & - & - & 1 & 1 & 1 & 3 \\
\hline Araneidae & & 6 & 10 & - & - & 5 & 21 \\
\hline Barychelidae & & - & - & - & - & 1 & 1 \\
\hline \multirow[t]{4}{*}{ Corinnidae } & & 3 & 4 & 12 & 10 & 5 & 34 \\
\hline & Castianeira sp.1 & - & - & $(2)$ & - & - & (2) \\
\hline & Castianeira sp.2 & - & - & $(1)$ & - & - & (1) \\
\hline & Creugas sp. 1 & $(1)$ & $(1)$ & - & $(1)$ & - & (3) \\
\hline \multirow[t]{2}{*}{ Deinopidae } & & - & - & - & - & 1 & 1 \\
\hline & Deinopis sp. 1 & - & - & - & - & $(1)$ & (1) \\
\hline Dipluridae & & - & - & 2 & 1 & - & 3 \\
\hline Gnaphosidae & & - & - & - & 2 & - & 2 \\
\hline \multirow[t]{2}{*}{ Hahniidae } & & 10 & - & 8 & 6 & 3 & 27 \\
\hline & Neohahnia sp.1 & $(7)$ & - & $(2)$ & $(1)$ & $(1)$ & $(11)$ \\
\hline \multirow[t]{2}{*}{ Linyphiidae } & & 5 & 12 & 24 & 9 & 7 & 57 \\
\hline & Meioneta sp.1 & - & - & $(2)$ & - & - & (2) \\
\hline \multirow[t]{8}{*}{ Oonopidae } & & 5 & 11 & 14 & 10 & 11 & 51 \\
\hline & Gamasomorpha sp.1 & (3) & - & $(2)$ & - & - & (5) \\
\hline & Hexapopha sp.1 & - & - & $(6)$ & $(5)$ & $(5)$ & (16) \\
\hline & Neotrops sp.1 & - & (3) & $(1)$ & (1) & (3) & (8) \\
\hline & Neotrops sp. 2 & - & $(2)$ & - & - & - & (2) \\
\hline & Neoxyphinus sp.1 & $(1)$ & - & $(1)$ & - & $(1)$ & (3) \\
\hline & $\begin{array}{l}\text { Opopaea concolor } \\
\text { (Blackwall, 1859) }\end{array}$ & - & (1) & - & - & - & (1) \\
\hline & Orchestina sp.1 & $(1)$ & - & - & - & - & $(1)$ \\
\hline \multirow[t]{2}{*}{ Oxyopidae } & & 2 & 1 & 1 & - & 1 & 5 \\
\hline & Hamataliwa sp.1 & - & $(1)$ & - & - & - & $(1)$ \\
\hline \multicolumn{2}{|l|}{ Palpimanidae } & 1 & 5 & 2 & 2 & 2 & 12 \\
\hline Brescov & $\begin{array}{r}\text { Otiothops hoeferi } \\
\text { ovit \& Bonaldo, } 1993\end{array}$ & (1) & $(5)$ & $(2)$ & $(2)$ & (2) & (12) \\
\hline \multirow[t]{3}{*}{ Pholcidae } & & 7 & - & 1 & 1 & 2 & 11 \\
\hline & Mesabolivar sp.1 & $(5)$ & - & - & - & - & (5) \\
\hline & Mesabolivar sp.2 & $(1)$ & - & $(1)$ & - & - & (2) \\
\hline
\end{tabular}




\begin{tabular}{|c|c|c|c|c|c|c|}
\hline Salticidae & 17 & 39 & 23 & 18 & 24 & 121 \\
\hline Breda sp.1 & - & $(7)$ & - & - & $(2)$ & (9) \\
\hline Corythalia sp.1 & - & $(1)$ & - & - & - & (1) \\
\hline Salticidae sp.1 & - & (1) & (3) & - & - & (4) \\
\hline Salticidae sp.2 & - & - & $(2)$ & - & - & (2) \\
\hline Salticidae sp.3 & - & - & $(1)$ & $(1)$ & - & (2) \\
\hline Salticidae sp.4 & - & (6) & - & (1) & - & (7) \\
\hline Salticidae sp.5 & $(2)$ & - & $(1)$ & (1) & - & (4) \\
\hline Salticidae sp.6 & (1) & - & - & - & (1) & (2) \\
\hline Salticidae sp.7 & - & - & (1) & (1) & - & (2) \\
\hline Salticidae sp. 8 & - & - & $(1)$ & - & - & (1) \\
\hline Scytodidae & 1 & 2 & 9 & 3 & 1 & 16 \\
\hline Scytodes sp.1 & - & - & $(1)$ & - & - & (1) \\
\hline Segestriidae & - & - & - & 3 & 1 & 4 \\
\hline \multirow{2}{*}{$\begin{array}{l}\text { Symphytognathidae } \\
\text { Anapistula aquytabuera } \\
\text { Reims \& Brescovit, } 2003\end{array}$} & 21 & 5 & 12 & 6 & 2 & 46 \\
\hline & (10) & (1) & $(2)$ & (5) & (2) & (20) \\
\hline \multirow{3}{*}{$\begin{array}{l}\text { Theridiidae } \\
\qquad \begin{array}{r}\text { Coleosoma floridanum } \\
\text { Banks, } 1900 \\
\text { Coleosoma } \text { sp.1 }\end{array}\end{array}$} & 12 & 14 & 9 & 24 & 19 & 78 \\
\hline & (2) & - & $(1)$ & - & (1) & (4) \\
\hline & - & - & (1) & (5) & - & (6) \\
\hline $\begin{array}{l}\text { Dipoena pumicata } \\
\text { (Keyserling, 1886) }\end{array}$ & - & - & - & (1) & - & (1) \\
\hline Dipoena sp.1 & - & - & $(1)$ & - & - & (1) \\
\hline Dipoena sp.2 & - & (1) & - & - & - & (1) \\
\hline Episinus sp.1 & - & - & - & - & (1) & (1) \\
\hline Guaraniella sp.1 & - & - & - & - & $(1)$ & (1) \\
\hline Stemmops sp.1 & - & - & - & (4) & - & (4) \\
\hline Thymoites sp.1 & - & $(5)$ & - & - & - & (5) \\
\hline Thymoites sp. 2 & - & - & - & $(2)$ & - & (2) \\
\hline Thymoites sp. 3 & - & - & - & $(1)$ & - & (1) \\
\hline Thomisidae & - & 3 & - & 2 & 5 & 10 \\
\hline \multicolumn{7}{|l|}{ Bucranium taurifrons } \\
\hline (O. Pickard-Cambridge, 1881) & - & - & - & $(1)$ & - & (1) \\
\hline Tmarus sp.1 & - & $(2)$ & - & - & - & (2) \\
\hline Uloboridae & 10 & 3 & - & - & 3 & 16 \\
\hline Uloborus sp.1 & (3) & - & - & - & - & (3) \\
\hline Zodariidae & 1 & 5 & 13 & 6 & 13 & 38 \\
\hline Epicratinus sp.1 & - & - & $(1)$ & - & & 1 \\
\hline Total $(\mathrm{N})$ & 110 & 126 & 148 & 123 & 146 & 653 \\
\hline Richness (S) & 13 & 17 & 24 & 20 & 15 & 52 \\
\hline
\end{tabular}

regardless of area size and degree of biotic integrity. This result may indicate that, because all fragments are in the same urban matrix, they share structural characteristics of the remaining vegetation that, in a way, homogenize the diversity of species present. These remnants of native vegetation are important habitats for the maintenance and conservation of these assemblages of ground spiders, since despite being located in an urban matrix and thus susceptible to anthropic pressures, these areas can conserve structural characteristics of the original natural habitat (Fernández et al. 2019), constituting refuges of fundamental importance for the conservation of regional biodiversity (e.g. Candiani et al. 2005, Nogueira et al. 2006, Haddad et al. 2011, Melo et al. 2011, Patucci et al. 2018, Samu et al. 2018).

The assemblage composition and the most abundant families in these fragments correspond to taxa commonly sampled in studies 


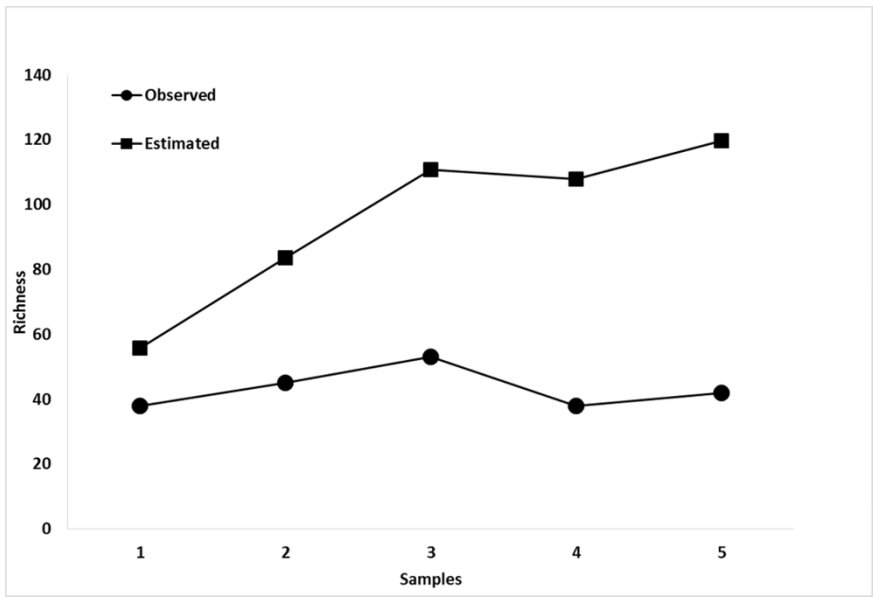

Figure 2. Sampled and estimated richness (Jackknife 1) of the assemblage of ground spiders (Arachnida, Araneae) associated with forest fragments in the urban area of Sinop - MT, Brazil.

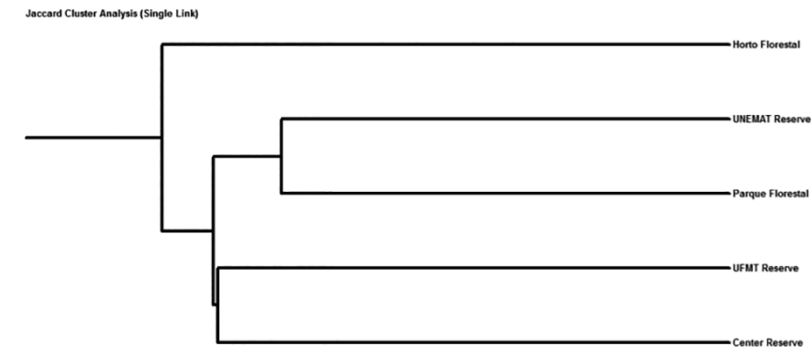

0. 5 similar

Figure 3. Jaccard Similarity Index for the assemblage of ground spiders (Arachnida, Araneae) associated with forest fragments in the urban area of Sinop - MT, Brazil.

evaluating the ground assemblages of spiders in the state of Mato Grosso (e.g. Castilho et al. 2005, Battirola et al. 2010, Anjos et al. 2017). Some of these families have specific behaviors or characteristics, such as the Theridiidae, key insect predators in many ecosystems, which are among the few families of spiders with a high degree of myrmecophagy (Liu et al. 2016). Also noteworthy are Linyphiidae, Lycosidae and Oonopidae, typical inhabitants of the ground environment, whose majority of species can occupy a wide variety of habitats, including open areas, despite being found at the ground level (Weeks \& Holtzer 2000, Jocqué \& Alderweireldt 2005, Fannes et al. 2008). Symphytognathidae are orb weavers that attach themselves to vegetation through radial threads that converge to the center of the web (Nogueira et al. 2006). They are small in size and usually collected with Berlese funnels, Winkler extractor or pitfall traps (Rheims \& Brescovit 2003).

These characteristics contribute to the understanding of the dominance of these families in different ground samplings. Azevedo et al. (2017) obtained similar results regarding spider assemblage composition, with Zodariidae and Lycosidae dominating in abundance and Salticidae and Theridiidae in species richness, in a forest fragment in an urban area of Fortaleza, state of Ceará. Carvalho \& Avelino (2010) reported Theridiidae, Salticidae, Araneidae and Ctenidae as the most abundant in José de Freitas, state of Piauí. Candiani et al.
(2005) observed that Linyphiidae, Zoridae and Theridiidae comprised the taxa with the highest density of ground activity in different urban forests in São Paulo. In forest fragments in Bahia, Dias et al. (2005) found Salticidae, Oonopidae, Pholcidae and Ctenidae as the most active groups on the ground. Despite revealing a certain similarity in assemblage composition, in terms of dominant taxa, these results show that spiders are present and active in these areas, playing an important role in maintaining the ecological processes existing in these habitats, mainly those associated with food webs (Uetz 1991, Wise 1993).

Only two of the species identified in this study occurred in the five fragments, namely, A. aquytabuera and $O$. hoeferi, characterizing the assemblage in the urban fragments in Sinop as having a dominance of small spiders, mainly hunters. Despite the observed high similarity between the assemblages, specimens of five families were exclusive in some of the analyzed fragments. For Symphytognathidae and Oonopidae specifically, the new records of A. aquytabuera and O. concolor in the Amazon are highlighted.

With this new record, the occurrence of A. aquytabuera is extended from the center-south of Brazil (Mato Grosso do Sul and Rio de Janeiro) (Rheims \& Brescovit 2003) to the southern Amazon. The low number of records of this species may be associated with its tiny size, which makes its collection and identification difficult. For O. concolor, which is considered a pantropical species introduced in Brazil (Platnick \& Dupérré 2009), a very pronounced invasive and synanthropic behavior was observed, which caused this species to be present in areas intensely disturbed by human activities. These include urban areas, houses, buildings or even caves (Brescovit et al. 2019), and, now, forest fragments in the urban matrix of Sinop. In this study, the species was found in Horto Florestal, a fragment with a regular IBI, characterized by anthropic pressures by the population. In addition to the new record reported in this study, in the Amazon of Mato Grosso State, O. concolor is also found in 37 other Brazilian locations in the states of Bahia, Mato Grosso do Sul, Minas Gerais, Rio de Janeiro, São Paulo, Paraná and Rio Grande do Sul (Brescovit et al. 2019).

The occurrence of new records such as these highlights the gaps in the knowledge of our biodiversity, warranting the expansion of sampling to different regions of the country, including urban areas, where the majority of the population is located. In general, spiders reflect changes in the structure of their assemblages in ecosystems altered by human action, and the main response is a decrease in species diversity and an increase in total abundance (Shochat et al. 2004). Therefore, species more resistant and adapted to these changes occupy the space of species that are eliminated from the habitat. In this respect, the impact caused by the introduction of exotic species in natural environments is noteworthy. Primack (1998) stated that, in occupying a habitat, these species grow in abundance at the expense of native species through competition and by limiting resources, which, in certain cases, can lead to the decline of native species. In the specific case of spiders, Brescovit et al. (2019) emphasized that studies on exotic and invasive spiders in the Neotropical Region are still scarce, but, in Brazil, there is a significant estimated number of species in this group, especially those with synanthropic behaviors.

Habitats that provide favorable foraging conditions allow different species of spiders to colonize them. According to Lessard-Therrien et al. (2018), the structure and ecological conditions of habitats are fundamental for determining the occurrence of spiders, since, for the 

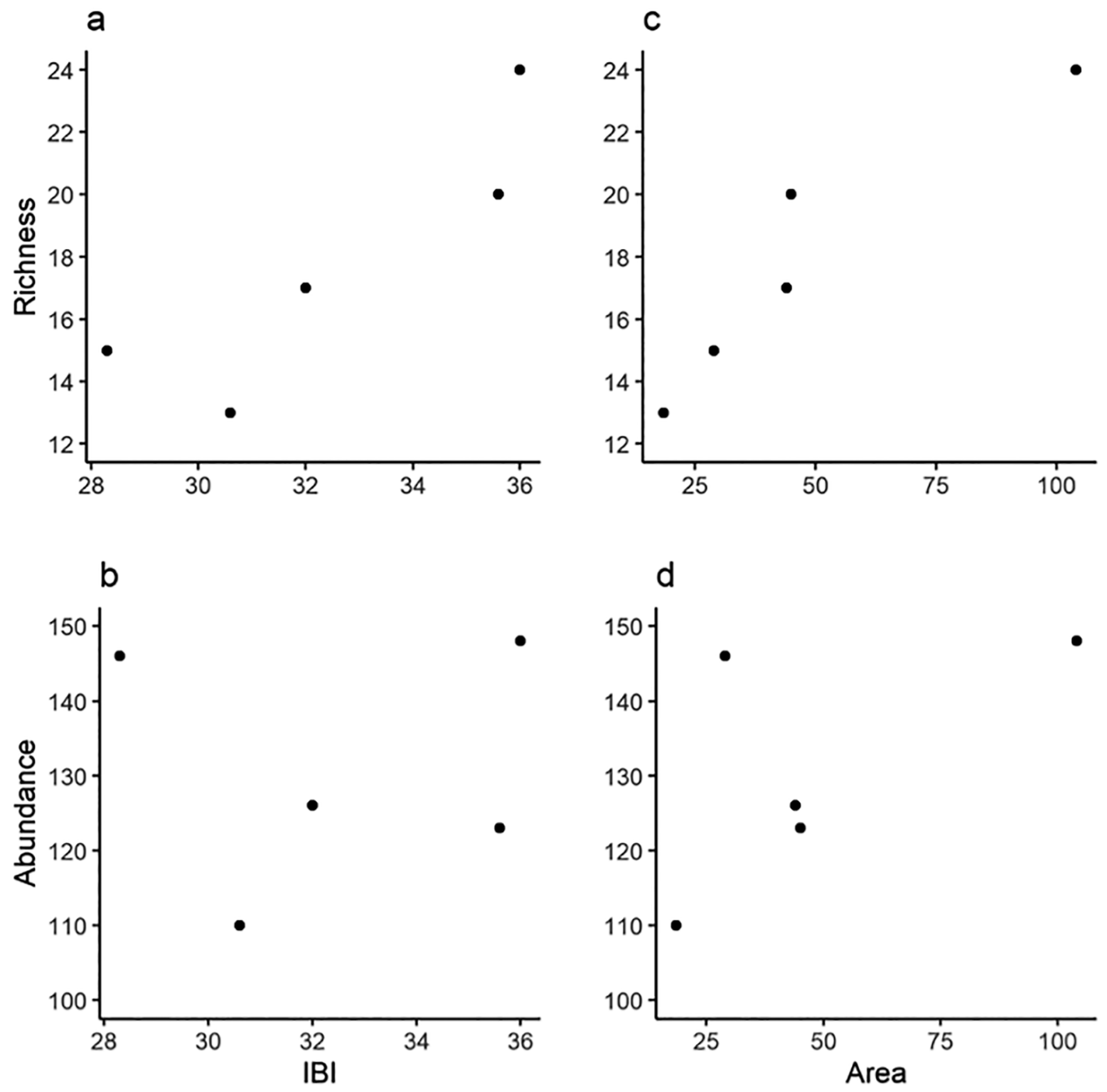

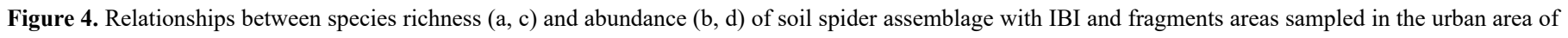
Sinop - MT, Brazil.

most part, they are generalist predators that use a wide variety of prey, even if prey populations are small (Sunderland \& Samu 2003). The dominance of hunting spiders found in this study is common in studies investigating the composition and structure of spider assemblages (Castilho et al. 2005, Battirola et al. 2004, 2010, Sena et al. 2010, Anjos et al. 2017, Yamazaki et al. 2017).

The physical structure of the environment has an important influence on the habitat preferences of spider species and, finally, on the composition of their assemblages (Uetz 1991). In this study, the IBI revealed that all fragments suffer from impacts generated by urbanization and they were categorized into low and regular biotic integrity conditions. The Parque Florestal and the UNEMAT Reserve were the areas that presented the best conditions in terms of IBI and were also the largest fragments evaluated in this study. In general, in urban areas, vegetation remnants are impacted mainly by the edge effect, which generates changes in abiotic (temperature, humidity, luminosity and wind speed) and biotic (abundance, richness and structure of biological communities) conditions (Andrade et al. 2019). This effect tends to be greater in smaller fragments, considering the proximity of the central region of this habitat to the peripheral regions, which are 
thus more susceptible to environmental disturbances. These changes in the physical environment influence the composition of the assemblages, preventing the population increase of some species but also providing better conditions for tolerant and more generalist species due to the quality of the habitat, including exotic species and species adapted to adverse conditions.

Fragment integrity depends on the maintenance of some characteristics such as fragment size, degree of isolation and time since the excision from the continuous forest, as these factors can directly influence the biodiversity associated with the area and, in a complex manner, the biodiversity present across the several fragments that occupy the landscape of a region (Turner 1996). The composition and diversity of the landscape can influence the size of the regional sets of species from which spiders can originate. Thus, the local variables that indicate the quality of the habitat are extremely important for determining the abundance of each species in these areas (Drapela et al. 2008).

The applied indices proved to be efficient in the diagnosis of habitat conditions, since they managed to numerically translate the conditions found in the field (Graciano-Silva et al. 2018) and directly correlate with the number of species found in the areas. The evaluation of species distribution according to fragment size demonstrates a variation in the distribution of the species abundance according to the size of the areas, with a tendency for larger fragments to maintain a greater number of species. This was observed in this study, in which Parque Florestal (103.98 ha) and the UNEMAT Reserve (45 ha), the two largest evaluated fragments, recorded the greatest species richness. The abundance of spiders did not follow the same pattern, with Parque Florestal (103.98 ha) and the UFMT Reserve (29 ha) recording more individuals. Results obtained by Benati et al. (2005) in inventories of spider communities in two remnants of the Atlantic Forest in the state of Bahia revealed similarities between the two fragments of different sizes, suggesting that the larger the area, the greater the species richness and abundance.

Studies carried out on urban fragments have shown an overall high diversity of spider species. However, variations in the composition of these assemblages may be associated with the type of biome, age, structure, presence of exotic species, degree of fragment integrity, as well as the degree of urbanization present in its surrounding matrix (Benati et al. 2005, Candiani et al. 2005, Dias et al. 2005, Bonaldo \& Dias 2010, Carvalho \& Avelino 2010, Stefani et al. 2012, Azevedo et al. 2017). In addition to these factors, the sampling effort, both in relation to temporal and spatial scales, also comprise an important point in the communities evaluations, including spiders, influencing the analysis (e.g. Coddington et al. 2009).

In our study, we used two methodologies, pitfall traps and miniWinkler, considering that both are complementary for the ground assemblages sampling (Silva et al. 2013, Carneiro et al. 2016). Sampling with pitfall traps occurred over 48 hours, remaining in the field, most of the time, for several days as carried out in other studies (Battirola et al. 2010, Anjos et al. 2017). However, in the urban green areas from Sinop, logistical issues such as the access to the interior of the fragments prevented sampling from being conducted for a longer period of time. We believe that the richness of spider species in these areas is greater than that recorded in our study, requiring complementary sampling and at different times of the year, in order to know the real richness associated with these important areas inserted in urban matrices.

As a result, the sampling is commonly characterized by the presence of singletons and doubletons species, which can represent, in terms of the richness of the assemblies, more than half of the total sampled (e. g. Allison et al. 1997; Novotny \& Basset 2000), as well as observed in the urban forest fragments evaluated in this study (59.6\% of the total species). Continuous sampling efforts in the studied environment tend to decrease the presence of these species, considering the greater probability of sampling (Lucky et al. 2002). Specifically for surveying the spider fauna, Coddington et al. (2009) confirmed that the high number of singletons in the samples is a result of the effects of the sampling effort, and factors commonly presented as the cause of the high presence of these species in the samples like the small body size, male-female ratio, cryptic behavior and a clumped distributions, failed to explain the singleton frequency. Coddington et al. (2009) state that "drastically greater sampling intensity in tropical arthropod inventory studies is required to yield realistic species richness estimates". Despite of this, the results of our study are relevant when considering the scarce knowledge of southern Amazon spider fauna and the need to expand this knowledge about regional biodiversity, contributing to its conservation, mainly in urban areas.

Knowledge of urban biodiversity and its distribution is very limited, especially in the case of small organisms (Savard et al. 2000). However, research on forest fragments in urban areas has surprised researchers due to the presence and vitality of organisms in the cities and their vicinities (Pickett et al. 2011). Therefore, this study provides an assessment of the importance of urban forest fragments as fundamental habitats for the survival of a high species richness, considering that the number of species of ground spiders suggests that these habitats constitute an environment rich in other species, insects and other invertebrates, mainly, which are used as food source by spiders. In this way, specific public policies for urban green areas aimed at their conservation must be encouraged so that their maintenance and stability is ensured.

\section{Acknowledgments}

Thanks are due to the Graduate Program in Environmental Sciences of the Federal University of Mato Grosso, University Campus of Sinop; the Research Support Foundation of the Mato Grosso State - FAPEMAT, for the fellowship grant awarded to GERS; the Coordination for the Improvement of Higher Education Personnel - CAPES (Finance code - 001); the Center for Biodiversity Studies in the Mato Grosso Amazon (NEBAM/UFMT); and the Zoological Collections Laboratory (LECZ) of the Butantan Institute, São Paulo - SP, Brazil. Financial assistance was provided to ADB by CNPq (case no. 303903/2019-8).

\section{Author Contributions}

Genefer E. R. dos Santos: Substantial contribution in the concept and design of the study; Contribution to data analysis and interpretation; Contribution to manuscript preparation; Contribution to critical revision, adding intellectual content. 
Kleber Solera: Substantial contribution in the concept and design of the study; Contribution to data analysis and interpretation; Contribution to manuscript preparation; Contribution to critical revision, adding intellectual content.

Cristiano A. da Costa: Contribution to data analysis and interpretation; Contribution to manuscript preparation; Contribution to critical revision, adding intellectual content.

Marinêz I. Marques: Contribution to data analysis and interpretation; Contribution to manuscript preparation; Contribution to critical revision, adding intellectual content.

Antonio D. Brescovit: Contribution to data analysis and interpretation; Contribution to manuscript preparation; Contribution to critical revision, adding intellectual content.

Leandro D. Battirola: Substantial contribution in the concept and design of the study; Contribution to data collection; Contribution to data analysis and interpretation; Contribution to manuscript preparation; Contribution to critical revision, adding intellectual content.

\section{Conflicts of interest}

The authors declare that they have no conflict of interest related to the publication of this manuscript.

\section{Ethics}

The authors confirm that the manuscript has been submitted solely to this journal and is not published, in press, or submitted elsewhere; Confirm that all the research meets the ethical guidelines, including adherence to the legal requirements of the study country. Confirm that you have prepared a complete text minus the title page, acknowledgments, and any running headers with author names, to allow blinded review.

\section{Data availability}

The data is not yet available on digital platforms, however all the material is deposited in zoological collections as reported in the manuscript.

\section{References}

ADIS, J. 2002. Recommended sampling techniques. In Amazonian Arachnida and Myriapoda (J. Adis ed.). Pensoft Publishers, Sofia, p.555-576.

ALLISON, A., SAMUELSON, A. \& MILLER, S.E. 1997. Patterns of beetles species diversity in Castanopsis acuminatissima (Fagaceae) trees studied with canopy fogging in mid-montane New Guinea rainforest. In Canopy Arthropods (N.E. Stork, J. Adis \& Didham, R.K. eds). Chapman \& Hall, London, p.224-236.

ANDRADE, A.C., FRANZINI, L.D. \& MESQUITA, D.O. 2019. Assessing the effect of urbanization on tropical forest dwelling teiid lizards. Ecol. Indic. 99:225-229.

ANJOS, K.C., BATISTELLA, D.A., BRESCOVIT, A.D., BATTIROLA, L.D. \& MARQUES, M.I. 2017. Ground-dwelling spiders (Arachnida, Araneae) in different vegetational formations in a Neotropical floodplain. Neotrop. Biol. Conserv. 12:171-180.

ARAÚJO, M.L.S., SANO, E.E., BOLFE, E.L., SANTOS, J.R.N., SANTOS, J.V. \& SILVA, F.B. 2019. Spatio temporal dynamics of soybean crop in the Matopiba region, Brazil (1990-2015). Land Use Policy 80:57-67.
AZEVEDO, R., MENEZES, K.G., BARBOSA, R.A., MATOS NETO, J.D.R., MONTEIRO, J.O.N., COUTINHO, A.G. \& SALES JÚNIOR, L.G. 2017. Aranhas epígeas de um fragmento de mata em área urbana em Fortaleza, Ceará, Brasil. Pesquisa e Ensino em Ciências Exatas e da Natureza 1:104-114.

BATTIROLA, L.D., MARQUES, M.I., ADIS, J. \& BRESCOVIT, A.D. 2004. Aspectos ecológicos da comunidade de Araneae (Arthropoda, Arachnida) em copas da palmeira Attalea phalerata Mart. (Arecaceae) no Pantanal de Poconé, Mato Grosso, Brasil. Rev. Bras. Entomol. 48:421-430.

BATTIROLA, L.D., MARQUES, M.I., BRESCOVIT, A.D., ROSADO NETO, G.H. \& ANJOS, K.C. 2010. Comunidade edáfica de Araneae (Arthropoda, Arachnida) em uma floresta sazonalmente inundável na região norte do Pantanal de Mato Grosso, Brasil. Biota Neotrop. 10. http://www. biotaneotropica.org.br/v10n2/pt/abstract?inventory+bn00210022010.

BENATI, K.B., SOUZA-ALVES, J.P., SILVA, E.A., PERES, M.C.L. \& COUTINHO, E.O. 2005. Aspectos comparativos das comunidades de aranhas (Araneae) em dois remanescentes de mata atlântica do Estado da Bahia, Brasil. Biota Neotrop. 5:1-9. https://doi.org/10.1590/S167606032005000200007.

BENATI, K.R., PERES, M.C.L., TINOCO, M.S. \& BRESCOVIT, A.D. 2010. Habitat structure of two fragments influencing leaf litter spider. Neotrop Biol Conserv. 5:39-46. https://doi.org/10.4013/nbc.2010.51.06.

BESTELMEYER, B.T., AGOSTI, D., LEEANNE, F., ALONSO, T., BRANDÃO, C.R.F., BROWN, W.L., DELABIE, J.H.C. \& SILVESTRE, R. 2000. Field techniques for the study of ground-living ants: An Overview, description, and evaluation. In Ants: Standart methods for measuring and monitoring biodiversity (D. Agosti, J.D. Majer, A. Tennant \& T. de Schultz, eds.). Smithsonian Institution Press, Washington, p.122-144.

BONALDO, A.B. \& DIAS, S.C. 2010. A structured inventory of spiders (Arachnida, Araneae) in natural and artificial forest gaps at Porto Urucu, Western Brazil, Amazonia. Acta Amazon. 40:357-372.

BOTELHO, M.T.S.L. \& SECCHI, D. 2014. O processo de colonização em Mato Grosso e o impacto sobre as sociedades indígenas: O caso de Sinop. Tellus 14:31-48.

BRESCOVIT, A.D., BONALDO, A.B., BERTANI, R. \& RHEIMS, C.A. 2002. Araneae. In Amazonian Arachnida and Myriapoda (J. Adis ed). Pensoft Publishers, Sofia, p.303-343.

BRESCOVIT, A.D., BONALDO, A.B., OTT, R. \& CHAVARI, J.L. 2019. To boldly go: on invasive goblin spiders in Brazil (Araneae, Oonopidae). Iheringia Sér. Zool. 109:e2019033. https://doi.org/10.1590/16784766e2019033

CANDIANI, D.F., INDICATTI, R.P. \& BRESCOVIT, A.D. 2005. Composição e diversidade da araneofauna (Araneae) de serapilheira em três florestas urbanas na cidade de São Paulo, São Paulo, Brasil. Biota Neotrop. 5:(1). http://www.biotaneotropica.org.br/v5n1a/pt/abstract?inventory+BN0080 $51 \mathrm{a} 2005$.

CARDOSO, P., PEKÁR, S., JOCQUÉ, R. \& CODDINGTON, J.A. 2011. Global patterns of guild composition and functional diversity of spiders. PLoS ONE 6:e21710. https://doi.org/10.1371/journal.pone.0021710.

CARNEIRO, A.C., BATISTELLA, D.A., BATTIROLA, L.D. \& MARQUES, M.I. 2016. Pitfall traps and mini-Winkler Extractor as complementary methods to sample soil Coleoptera. Neotrop. Entomol. 45:28-32.

CARVALHO, S.L. \& AVELINO, M.T.L. 2010. Composition and diversity of the spider fauna (Arachnida, Araneae) from Nazareth Farm, José de Freitas Municipality, Piauí, Brazil. Biota Neotrop. 10(3): http://dx.doi.org/10.1590/ S1676-06032010000300001.

CASTILHO, A.C.C., MARQUES, M.I., ADIS, J. \& BRESCOVIT, A.D. 2005. Distribuição sazonal e vertical de Araneae em área com predomínio de Attalea phalerata Mart. (Arecaceae), no Pantanal de Poconé, Mato Grosso, Brasil. Amazoniana 18:215-239.

CODDINGTON, J.A., AGNARSSON, I., MILLER, J.A., KUNTNER, M. \& HORMIGA, G. 2009. Undersampling bias: the null hypothesis for singleton species in tropical arthropod surveys. J. Anim. Ecol. 78:573-584.

DIAS, M.F.R., BRESCOVIT, A.D. \& MENEZES, M. 2005. Aranhas de solo (Arachnida: Araneae) em diferentes fragmentos florestais no sul da Bahia, Brasil. Biota Neotrop. 5(1). http://dx.doi.org/10.1590/S167606032005000200012 . 
DIAS, S.C., CARVALHO, L.S., BONALDO, A.B. \& BRESCOVIT, A.D. 2010. Refining the establishment of guilds in Neotropical spiders (Arachnida: Araneae). J. Nat. Hist. 44:219-239.

DRAPELA, T., MOSER, D., ZALLER, J.G. \& FRANK, T. 2008. Spider assemblages in winter oil seed rape affected by landscape and site factors. Ecography 31:254-262.

FANNES, W., DE BAKKER, D., LOOSVELDT, K. \& JOCQUÉ, R. 2008. Estimating the diversity of arboreal oonopid spider assemblages (Araneae, Oonopidae) at Afrotropical sites. J. Arach. 36:322-330.

FERNÁNDEZ, I.C., WU, J. \& SIMONETTIE, J.A. 2019. The urban matrix matters: Quantifying the effects of surrounding urban vegetation on natural habitat remnants in Santiago de Chile. Landsc. Urban Plan. 187:181-190.

FOX, J. \& WEISBERG, S. 2019. An $\{R\}$ Companion to Applied Regression. Thousand Oaks CA: Sage. URL: https://socialsciences.memaster.ca/jfox/ Books/Companion/

GONG, C., YUA, S., JOESTING, H. \& CHENC, J. 2013. Determining socioeconomic drivers of urban forest fragmentation with historical remote sensing images Chong Feng. Landsc. Urban Plan. 117:57-65.

GRACIANO-SILVA, T., MELLO, K. \& CARDOSO-LEITE, E. 2018 Adaptação e eficiência de um índice de integridade biótica para análise da sustentabilidade em florestas urbanas. Gaia Scientia. 12:60-75.

HADDAD, G.Q., CIVIDANES, F.J. \& MARTINS, I.C.F. 2011. Diversidade de myrmecofauna e araneofauna associadas com agroecossistema e fragmentos florestais e sua interação com carabídeos e Staphylinidae (Coleoptera). Fla. Entomol. 94:500-509.

HÖFER, H. \& BRESCOVIT, A.D. 2001. Species and guild structure of a Neotropical spider assemblage (Araneae) from Reserva Ducke, Amazonas, Brazil. Andrias 15:99-119.

JOCQUÉ, R. \& ALDERWEIRELDT, M. 2005. Lycosidae: the grassland spiders. Acta Zool. Bulg. 1:125-130.

LESSARD-THERRIEN, M., HUMBERT, J., HAJDAMOWICZ, I., STAŃSKA, M., KLINKA R.V., LISCHERA, L. \& ARLETTAZ, R. 2018. Impacts of management intensification on ground-dwelling beetles and spiders in seminatural mountain grasslands. Agr. Ecosyst. Environ. 251:59-66.

LIU, J., MAY-COLLADO, L.J., PEKÁR, S. \& AGNARSSON, I. 2016. A revised and dated phylogeny of cobweb spiders (Araneae, Araneoidea, Theridiidae): A predatory Cretaceous lineage diversifying in the era of the ants (Hymenoptera, Formicidae). Mol. Phylogenet. Evol. 94:658-675.

LUCKY, A., ERWIN, T.L. \& WITMAN, J.D. 2002. Temporal and spatial diversity and distribution of arboreal Carabidae (Coleoptera) in a western Amazonian rain forest. Biotropica 34:376-386.

MACNEELY, N., LAMBSHEAD, P.J.D., PATERSON, G.L.J. \& GAGE, J.D. 1997. Biodiversity Pro: free statistics software for ecology. The Natural History Museum; The Scottish Association for Marine Science, London.

MAJOR, R.E., FIONA, G.G., CHRISTIE, F. \& COLGAN, M.G.D. 2006. Variation in wolf spider (Araneae: Lycosidae) distribution and abundance in response to the size and shape of woodland fragments. Biol. Conserv. 132:98-108.

MALUMBRES-OLARTE, J., BARRATT, B.I.P., VINK, C.J., PATERSONA, A.M., CRUICKSHANKA, R.H., FERGUSON, C.M. \& BARTON, D.M. 2013. Habitat specificity, dispersal and burning season: Recovery indicators in New Zealand native grassland communities. Biol. Conserv. 160:140-149.

MARC, P., CANARD, A. \& YSNEL, F. 1999. Spiders (Araneae) useful for pest limitation and bioindication. Agr. Ecosyst. Environ. 74:229-273.

MCKINNEY, M.L. 2006. Urbanization as a major cause of biotic homogenization. Biol. Conserv. 127:247-260.

MELO, T.S., ANDRADE, A.R.S., BENATI, K.R., PERES, M.C.L. \& DIAS, M.A. 2011. Panorama da araneofauna de fragmentos florestais em Salvador, Bahia, Brasil. Sitientibus Ser. Ci. Biol. 11:37-47.

MESTRE, L.A.M. \& GASNIER, T.R. 2008. Populações de aranhas errantes do gênero Ctenus em fragmentos florestais na Amazônia Central. Acta Amazon. 38:159-164.
NOGUEIRA, A.A., PINTO-DA-ROCHA, R. \& BRESCOVIT, A.D. 2006. Comunidade de aranhas orbitelas (Arachnida-Araneae) na região da Reserva Florestal do Morro Grande, Cotia, São Paulo, Brasil. Biota Neotrop. 6 (2). http:// www.biotaneotropica.org.br/v6n2/pt/abstract?article+bn00906022006.

NOVOTNY, V. \& BASSET, Y. 2000. Rare species in communities of tropical insect herbivores: pondering the mystery of singletons. Oikos 89: 564-572.

NYFFELER, M. \& BIRKHOFER, K. 2017. An estimated 400-800 million tons of prey are annually killed by the global spider community. The Science of Nature. 104:30

OKSANEN, J., BLANCHET, F.G., FRIENDLY, M., KINDT, R., LEGENDRE, P., MCGLINN, D., MINCHIN, P.R., O'HARA, R.B., SIMPSON, G.L., SOLYMOS, P., STEVENS, M.H.H., SZOECS, E. \& WAGNER, H. 2019. Vegan: Community Ecology Package. R package version 2.5-6. https:// CRAN.R-project.org $/$ package $=$ vegan

OLIVEIRA, U., BRESCOVIT, A.D. \& SANTOS, A.J. 2017. Sampling effort and species richness assessment: a case study on Brazilian spiders. Biodivers. Conserv. 26:1481-1493.

PATUCCI, N., OLIVEIRA-FILHO, L.C., SILVA, C.B.D., OLIVEIRA, D.D., BARETTA, D. \& BRESCOVIT, A. 2018. Bioindicadores edáficos de fragmentos florestais urbanos da cidade de São Paulo (SP). Rev. Depart. Geografia. 36:77-90.

PICKETT, S.T.A., CADENASSO, M.L., GROVE, J.M., BOONE, C.G., GROFFMAN, P.M., IRWINE, E., KAUSHAL, S.S., MARSHALL, V., MCGRATH, B.P., NILONI, C.H., POUYAT, R.V., SZLAVECZ, K., TROY, A. \& WARRENM, P. 2011. Urban ecological systems: Scientific foundations and a decade of progress. J. Environ Manage. 92:331-362.

PLATNICK, N.I. \& DUPÉRRÉ, N. 2009. The goblin spider genera Opopaea and Epectris (Araneae, Oonopidae) in the New World. Sou. Mus. Novit. 3649:1-43.

PRIANTE-FILHO, N., VOURLITS, G.L., HAYASHI, M.M.S., NOGUERIA, J.S., CAMPELO, J. \& NUNES, P.C. 2004. Comparison of the mass and energy exchange of a pasture and a mature transitional tropical forest of the Southern Amazon Basin during a seasonal transition. Glob. Change Biol. 10:863-876.

PRIMACK, R.B. 1998. Essentials of Conservation Biology. Sinauer Associates, Sunderland, 660p.

R CORE TEAM. 2020. R: A language and environment for statistical computing. R Foundation for Statistical Computing, Vienna, Austria. URL https:// www.R-project.org/

RENÓ, V. \& NOVO, E. 2019. Forest depletion gradient along the Amazon floodplain. Ecol. Indic. 98:409-419.

RHEIMS, C.A \& BRESCOVIT, A.D. 2003. Description of six new species of Anapistula Gertsch (Araneae, Symphytognathidae) from Brazil. Bull. Br. Arachnol. Soc. 12:324-330.

RODRÍGUEZ-RODRÍGUEZ, S.E., SOLÍS-CATALÁNA, K.P. \& VALDEZMONDRAGÓN, A. 2015. Diversity and seasonal abundance of anthropogenic spiders (Arachnida: Araneae) in different urban zones of the city of Chilpancingo, Guerrero, Mexico. Rev. Mex. Biodivers. 86:962-971.

ROSA, M.G., BRESCOVIT, A.D., BARETTA, C.R.D.M., SANTOS, J.C.P., OLIVEIRA FILHO, L.C.L. \& BARETTA, D. 2019. Diversity of soil spiders in land use and management systems in Santa Catarina, Brazil. Biota Neotrop. 19(2): e20180619. http://dx.doi.org/10.1590/1676-0611-bn-2018-0619.

SAMU, F., HORVÁTH, A., NEIDERT, D., BOTOSA, E. \& SZITAA, E. 2018. Metacommunities of spiders in grassland habitat fragments of an agricultural landscape. Basic Appl. Ecol. 31:92-103.

SANTOS, R.C.; LIMA, M.; JUNIOR, C.A.S. \& BATTIROLA, L.D. 2019. Disordered conversion of vegetation committees connectivity between forest fragments in the Brazilian Legal Amazon. Appl Geography. 111:102082.

SAVARD, J.L., CLERGEAU, P. \& MENNECHEZ, G. 2000. Biodiversity concepts and urban ecosystems. Landsc. Urban Plan. 48:131-142.

SENA, D.U., PERES, M.C.L., TEIXEIRA, R.R., DOMINGOS, B.S. \& FONTOURA, T. 2010. Composition and guilds of spiders (Arachnida: Araneae) in the trees canopies of an urban forest fragment, Salvador, Bahia, Brazil. Rev. Bras. Biocienc. 16:24-33. 
SHOCHAT, E., STEFANOV, W.L., WHITEHOUSE, M.E.A. \& FAETH S.H. 2004. Urbanization and spider diversity: influences of human modification of habitat structure and productivity. Ecol. Appl. 14:268280.

SILVA, D. \& CODDINGTON, J.A. 1996. Spider of Paktiza (Madre de Dios, Peru): richness and notes on community structure. In Manu: the biodiversity of Southeastern Peru (Wilson. D.E. \& Sandoval, A. eds.). Smithsonian Institution, Washington, p.253-311.

SILVA, F.H.O., DELABIE, J.C.H., SANTOS, G.B., MEURER, E. \& MARQUES, M.I. 2013. Mini-Winkler extractor and pitfall trap as complementary methods to sample Formicidae. Neotrop. Entomol. 42:351-358.

STEFANI, V., GARCIA, K., VECCHIA, C., SILVA, L.A., GUIMARÃES, B., TIZO-PEDROSO, E., MACHADO, E.O., BRESCOVIT, A.D. \& DELCLARO, K. 2012. Mating behaviour, nympho-imaginal development and description of a new Mesabolivar species (Araneae: Pholcidae) from the Brazilian dry forest. J. Nat. Hist. 46:2117-2129.

SUNDERLAND, K. \& SAMU, F. 2003. Effects of agricultural diversification on the abundance, distribution, and pest control potential of spiders: a review. Entomol. Exp. Appl. 95:1-13.

TURNER, I.M. 1996. Species loss in fragments of tropical rain forest: a review of the evidence. Department of Botany, National University of Singapore, Singapore.
UEHARA-PRADO, M., OLIVEIRA FERNANDES, J.F., MOURA, A.B., MACHADO, G., SANTOS, A.J., VAZ-DE-MELLO, F.Z. \& FREITAS, A.V.L. 2009. Selecting terrestrial arthropods as indicators of small-scale disturbance: $A$ primary approach in Brazilian Atlantic Forest. Biol. Conserv. 142:1220-1228.

UETZ, G.W. 1991. Habitat structure and spider foraging. In Habitat structure: the physical arrangement of objects in space (Bell, S.S., Mccoy, E.D. \& Mushinsky, H.R. eds.). Chapman \& Hall, London, p.325-348.

WEEKS JR., R.D. \& HOLTZER, T.O. 2000. Habitat and season in structuring ground-dwelling spider (Araneae) communities in a shortgrass steppe ecosystem. Environ. Entomol. 29:1164-1172.

WICKHAM, H. 2016. ggplot2: Elegant Graphics for Data Analysis. SpringerVerlag, New York.

WISE, D.H. 1993. Spiders in ecological webs. Cambridge Univ. Press, Cambridge, U.K. 328p.

WORLD SPIDER CATALOG. 2020. Version 21.0 World Spider Catalog. Natural History Museum. Disponível em: https://wsc.nmbe.ch/Acesso em 30/05/2020.

YAMAZAKI, L., VINDICA, V.F., BRESCOVIT, A.D., MARQUES, M.I. \& BATTIROLA, L.D. 2017. Temporal variation in the spider assemblage (Arachnida, Araneae) in canopies of Callisthene fasciculata (Vochysiaceae) in the Brazilian Pantanal biome. Iheringia Ser. Zool. 107:p.e2017019. http:// dx.doi.org/10.1590/1678-4766e2017019. 